\title{
Pengaruh Pembagian Sisa Hasil Usaha (SHU) Terhadap Penambahan Modal Usaha Anggota Koperasi "Cahaya Pertama Mandiri"
}

\author{
Mulyati $^{1}$, Rini Anggriani ${ }^{2}$ \\ yhatisweet19@gmail.com ${ }^{1}$, rinianggriani@universitasbumigora.ac.id ${ }^{2}$
}

STIE Yapis Dompu ${ }^{1}$, Universitas Bumigora ${ }^{2}$

\begin{abstract}
Abstrak
Penelitian ini bertujuan untuk mengembangkan dan memotivasi anggota koperasi agar dapat mengelola modal usaha sehingga dapat meningkatkan besarnya sisa hasil usaha (SHU) yang akan didapatkan oleh masing-masing anggota koperasi, sehingga anggota koperasi yang pasif menjadi anggota yang lebih aktif. Karna perkembangan suatu koperasi tergantung dari bagaimana besarnya partisipasi dari anggota koperasi. Metode penelitian menggunakan jenis penelitian kuantitatif. Teknik pengumpulan data menggunakan kuesioner dan wawancara terstruktur kepada 83 orang yang dijadikan sebagai responden penelitian, selanjutnya data dari responden tersebut diolah menggunakan aplikasi SPSS versi 21. Dari hasil pengolahan data penelitian yang dilakukan dapat disimpulkan bahwa pembagian SHU koperasi menujukan pengaruh yang positif dan signifikan terhadap penambahan modal usaha anggota koperasi, dengan taraf signifikasi sebesar 0,000. Hasil penelitian menujukan bahwa semakin tinggi SHU koperasi maka akan semakin meningkatkan tambahan modal usaha yang diterima oleh anggota Cahaya Pertama Mandiri.
\end{abstract}

Kata kunci : sisa hasil usaha, penambahan modal.

\begin{abstract}
This study aims to develop and motivate cooperative members to be able to manage business capital so as to increase the amount of residual income (SHU) that will be obtained by each member of the cooperative, so that passive cooperative members become more active members. Because the development of a cooperative depends on how big the participation of members of the cooperative is. The research method uses quantitative research. The data collection techniques used questionnaires and structured interviews with 83 people who were used as research respondents, then the data from these respondents were processed using the SPSS version 21 application. From the results of research data processing, it can be concluded that the distribution of SHU cooperatives shows a positive and significant effect on the addition of business capital of cooperative members, with a significance level of 0.000. The results show that the higher the SHU of the cooperative, the more it will increase the additional business capital received by the members of Cahaya Pertama Mandiri.
\end{abstract}

Keywords: residual income, additional capital. 


\section{Pendahuluan.}

Covid-19 yang terjadi pada tahun 2020 melanda masyarakat Indonesia dan Dunia. Akibat dari adanya wabah tersebut, kondisi ekonomi diberbagai belahan negara mengalami kemerosotan dan berpotensi dilanda resesi. Dampak lain dari wabah pandemic covid-19 banyak perusahaan mengalami penurunan laba akibat dari adanya kebijakan beberapa Negara yang memberlakukan lock down dan memberlakukan Work From Home (WFH) termasuk beberapa propinsi strategis yang masuk pada red zone ada di Indonesia. Diberlakukannya WFH berkontribusi pada banyaknya pegawai yang terpaksa dirumahkan tampa kepastian hingga berujung pada banyaknya pegawai yang mengalami pemutusan hubungan kerja. Salah satu sector yang cukup rentan terhadap adanya krisis adalah sector koperasi. Koperasi merupakan kekuatan fundamental dan ujung tombak peningkatan ekonomi masyarakat.

Koperasi Cahaya Pertama Mandiri adalah salah satu UKM (Usaha Kecil Menengah) yang beralamat di Lingkungan Rato No.03 Kelurahan Karijawa Kecamatan Dompu Kabupaten Dompu, yang menjalankan kegiatan usaha pokok sebagai jasa koperasi simpan pinjam. Koperasi Cahaya Peratama Mandiri memiliki 12 orang karyawan. Pembagian sisa hasil usaha (SHU) Koperasi Cahaya Pertama Mandiri di lakukan selama 1 tahun sekali dan pembagian sisa hasil usaha (SHU) dilakukan pada saat Rapat Anggota Tahunan (RAT). Sisa hasil usaha (SHU) yang dibagikan pada masing-masing anggota dapat anggota gunakan untuk menambah modal usaha atau di gunakan untuk keperluan lain anggota koperasi sesuai dengan kebutuhan anggota koperasi.

Pembagian sisa hasil usaha (SHU) Koperasi Cahaya Pertama Mandiri dari tahun 2017 sampai dengan tahun 2019 cenderung mengalami kenaikan. Data terkait dengan pembagian sisa hasil usaha (SHU) di lihat dari laporan keuangan koperasi cahaya pertama mandiri adalah sebagai berikut:

\begin{tabular}{ccc}
\multicolumn{3}{c}{ Tabel 1 Pembagian SHU Koperasi Cahaya Pertama Mandiri } \\
\hline Tahun & Sisa Hasil Usaha & Modal Koperasi \\
\hline 2017 & 42.786 .440 & 336.166 .022 \\
2018 & 43.904 .855 & 402.149 .013 \\
2019 & 54.081 .747 & 476.440 .546 \\
& & \\
\hline
\end{tabular}

Dari data di atas dapat di lihat bahwa data simpanan anggota dari tahun 2017, SHU berjumlah Rp. 42.786.440, modal usaha berjumlah Rp. 336.166.022. Peningkatan terjadi pada tahun 2018, SHU berjumlah Rp. 43.904. 855, modal usaha berjumlah Rp. 402.149.013. Peningkatan kembali terjadi di tahun 2019, SHU berjumlah Rp. 54.081.747, modal usaha berjumlah Rp. 476.440.546. Di lihat dari tabel dan uraian di atas dapat disimpulkan bahwa pembagian sisa hasil usaha mempengaruhi penambahan modal usaha anggota Koperasi Cahaya Pertama Mandiri. 
Pertumbuhan perkoperasian di Indonesia sangat pesat dan masih eksis hingga saat ini adalah, di Daerah Dompu telah mencapai 385 koperasi, salah satunya adalah Koperasi Cahaya Pertama Mandiri. Namun, banyak juga koperasi yang mengalami kegagalan hingga berujung pada kebangkrutan ataupun tidak beroperasi lagi dikarenakan kurangnya pengetahuan manajemen perkoperasian, kurangnya pengetahuan bagaimana cara menjalankan perkopersian hingga kesulitan dalam mempertahankan keberlangsungan koperasi tersebut. Menurut (Mulyanti \& Rina, 2017) Modal bagi koperasi memiliki peranan penting dalam memperbesar volume usaha yang akan berimbas pada laba yang diperoleh. Selain modal, intensitas pemberian pinjaman pada anggota juga memiliki peran dalam meningkatkan pendapatan Koperasi berupa SHU. Sementara menurut (Malinda, 2015) tanpa adanya modal, suatu usaha yang bersifat ekonomis tidak akan dapat berjalan sebagaimana mestinya. Besar kecilnya modal yang ada pada koperasi akan berpengaruh terhadap aktivitas koperasi itu sendiri, dengan demikian faktor modal dalam koperasi ini merupakan salah satu alat yang ikut menentukan maju mundurnya koperasi.

Hasil penelitian terdahulu telah dilakukan oleh (Suteja, 2016) bahwa modal sendiri berpengaruh signifikan terhadap terhadap perolehan SHU dengan t-hitung lebih besar dari pada $\mathrm{t}$ tabel. Temuan (Malinda, 2015) menemukan sisa hasil usaha koperasi dapat dipengaruhi oleh jumlah anggota dan simpanan anggota. Lebih lanjut menurut (Malinda, 2015) Dalam sebuah koperasi, keanggotaannya memiliki karakteristik yang membedakannya dengan badan usaha lain. Menurut (Mulyanti \& Rina, 2017) Modal bagi koperasi memiliki peranan penting dalam memperbesar volume usaha yang akan berimbas pada laba yang diperoleh. Selain modal, intensitas pemberian pinjaman pada anggota juga memiliki peran dalam meningkatkan pendapatan Koperasi berupa Sisa Hasil Usaha. Dalam hasil temuanya (Mulyanti \& Rina, 2017) menunjukkan adanya pengaruh yang berbanding terbalik antara modal sendiri dan pemberian pinjaman, serta peningkatan SHU dapat ditingkatkan melalui pemberian pinjaman. Artinya peningkatan modal anggota tidak selalu bersumber dari pembagian sisa hasil usaha.

Hasil penelitian (Astary, 2015) simpanan anggota berpengaruh signifikan terhadap sisa hasil usaha. Penelitian (Setiyono, 2009) modal sendiri, modal asing dan volume usaha berpengaruh signifikan terhadap sisa hasil usaha. Sari dan Susanti (2015) Hasil penelitiannya yaitu modal sendiri, modal luar dan volume usaha secara bersama-sama mempengaruhi sisa hasil usaha (SHU). Penelitian (Mailiya, 2005) ada pengaruh yang signifikan antara modal sendiri dan modal pinjaman terhadap SHU. Hasil berbeda ditemukan pada (Thamrin, 2013) simpanan anggota secara parsial tidak berpengaruh pada peningkatan SHU. Dari beberapa hasil penelitian yang ada terdapat hasil yang tidak konsisten sehingga menjadi celah dilakukanya pengkajian lebih lanjut.

\section{Tinjauan Pustaka \\ Pengertian Sisa Hasil Usaha (SHU)}

Sisa Hasil Usaha (SHU) adalah selisih dari seluruh pemasukan atau permintaan (venue) dengan biaya-biaya atau biaya total (total cost) dalam satu tahun buku. SHU koperasi adalah pendapatan koperasi yang peroleh dalam satu tahun buku di kurang dengan biaya, penyusutan, dan kewajiban lain termaksud pajak dalam tahun buku Yang bersangkutan. Dengan mengacu pada pengetian di atas, maka besarnya SHU yang di terima oleh setiap Anggota berbeda, tergantung besarnya partisipan modal dan transaksi anggota terhadap pembentukan pendapatan koperasi. Keuntungan koperasi biasa disebut dengan istilah SHU. Berdasarkan UU No. 25 Tahun 1992 Pasal 45, SHU Koperasi adalah Pendapatan Koperasi yang diperoleh dalam satu 
tahun buku dikurangi dengan biaya penyusutan dan kewajiban lainnya termasuk pajak dalam satu tahun buku yang bersangkutan (Suteja, 2016).

\section{Rumus Sisa Hasil Usaha (SHU) Koperasi}

SHU koperasi adalah pendapatan koperasi yang didapat dalam satu tahun buku di kurangi dengan biaya, penyusutan serta kewajiban termasuk pajak dalam tahun buku. SHU sendiri bukan berupa keuntungan yang diperoleh dari hasil saham seperti PT. Namun, SHU adalah keutungan yang usahanya dibagi sesuai dengan aktivitas ekonomi anggota koperasi sehingga besaran SHU yang didapat oleh anggota akan berbeda. Keuntungan besar ataupun kecil dari koperasi tersebut tergantung besarnya SHU yang berasal dari anggota. Berikut adalah cara meghitung SHU adalah sebagai berikut:

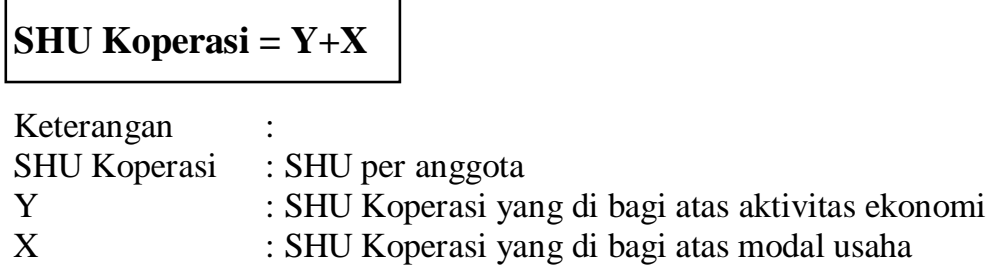

Untuk menghitung SHU koperasi, maka perlu diperhatikan beberapa hal berikut : 1) SHU berasal dari pendapatan anggota dan bukan anggota, 2) Pendapatan anggota terdiri dari jasa usaha dan jasa modal, karena setiap anggota koperasi akan menerima SHU sesuai dengan partisipasinya baik itu jasa usaha atau jasa modal.

Menghitung jasa usaha semua anggota $=\%$ jasa usaha $x$ SHU
Menghitung jasa modal semua anggota $=\%$ jasa modal $x$ SHU

Untuk menghitung sisa hasil usaha (SHU) salah seorang anggota dicari jasa modal dan jasa usahaya dulu secara perseorangan baru di bandingkan dengan seluruh penjualan dan modal anggota koperasi.

Jasa usaha seorang anggota $=$ (pembeliannya : penjualan anggota koperasi) $\mathrm{x}$ jasa usaha semua anggota Jasa modal seorang anggota $=($ simpanannya modal anggota koperasi $) \mathrm{x}$ jasa modal semua anggota .

Dasar pembagian SHU ditentukan dalam undang-Undang tentang pokok-pokok perkoperasian. Pembagian sisa hasil usaha koperasi pada dasarnya ditentukan cadangan. Di kembalikan pada anggota sesuai dengan jasa masing-masing anggota di pergunakan untuk kepentingan anggota seperti pendidikan/sosial dan untuk kepentingan umum, yaitu pembangunan daerah kerja. Sisa hasil usaha koperasi berasal dari kegiatan usaha dalam melayani anggota atau transaksi antara koperasi dengan anggota, tetapi pembagian sisa hasil usaha kepada anggota menurut jasa masing-masing hanya terbatas pada sisa hasil usaha yang di peroleh dari transaksi-transaksi antara koperasi dengan anggota. 


\section{Pengertian Modal Usaha}

Seperti halnya bentuk badan usaha yang lain, untuk menjalankan kegiatan usahanya koperasi memerlukan modal. Menurut undang-undang Republik Indonesia nomor 17 tahun 2012, adapun modal koperasi terdiri atas modal sendiri dan modal pinjaman modal sendiri meliputi sumber modal sebagai berikut:

a. Simpanan pokok; Simpanan pokok adalah sejumlah uang yang wajib di bayarkan oleh anggota kepada koperasi pada saat masuk menjadi anggota, simpanan pokok tidak dapat diambil kembali selama yang bersangkutan masih menjadi anggota koperasi, Simpanan pokok jumlahnya sama untuk setiap anggota

b. Simpanan wajib; Simpanan wajib adalah simpanan tertentu yang harus di bayarkan oleh anggota kepada koperasi dalam waktu dan kesempatan tertentu, misalnya tiap bulan dengan jumlah simpanan yang sama setiap bulannya. Simpanan wajib tidak dapat di ambil kembali selama yang bersangkutan masih menjadi anggota koperasi

c. Simpanan khusus/lain-lain misalnya simpanan sukarela(simpanan yang dapat di ambil kapan saja) simpanan kurban dan deposito berjangka

d. Dana cadangan; Dana cadangan adalah sejumlah uang yang di peroleh dari penyisihan sisa hasil usaha, yang di maksud untuk menumpukan modal sendiri, pembagian kepada anggota yang keluar dari keanggotaan koperasi dan untuk menutup kegiatan usaha bila di perlukan

e. Hibah; Hibah adalah sejumlah uang atau barang modal yang dapat di nilai dengan uang yang di terima dari pihak lain yang bersifat hibah/pemberian dan tidak mengikat.

\section{Penggunaan Modal Koperasi}

Penggunaan dan modal yang bermanfaat pada dasarnya koperasi berusaha memenuhi kebutuhan para anngotanya. Dalam rangka memenuhi kebutuhan tersebut, modal koperasi dapat dipergunakan untuk investasi dan dapat pula di gunakan untuk modal kerja. modal kerja adalah modal yang dipergunakan oleh koperasi untuk menjalankan seperti koperasi simpan pinjam utuk dipinjamkan pada anggota lain yang memerlukan pinjaman.

\section{Metodologi Penelitian}

Pada penelitian ini jenis penelitian yang digunakan adalah kuantitatif. Penelitian kuantitatif dapat diartikan sebagai metode penelitian yang berlandaskan pada filsafat positifisme, digunakan untuk meneliti pada populasi atau sampel tertentu, analisis data bersifat kuantitatif atau statistik dengan tujuan untuk menguji hipotesis yang telah ditetapkan (Sugiyono, 2017). Pada penelitian ini yang dijadikan populasi adalah seluruh anggota koperasi cahaya pertama mandiri yaitu 225 orang anggota. Teknik pengambilan sampel menggunakan simple random sampling hal ini dilakukan karena anggota populasi memiliki peluang yang sama untuk dipilih menjadi sampel. Karna menggunakan simple random sampling dari 225 populasi peneliti mengambil 83 orang atau dari populasi sebagai sampel dikarenakan 83 orang anggota tersebut selalu berperan aktif dan secara dominan ikut serta dalam segala kegiatan koperasi cahaya pertama mandiri.

Jenis data yang digunakan dalam penelitian ini adalah data primer. Sumber data dalam penelitian ini berasal dari tanggapan responden atas kuesioner yang diajukan oleh peneliti. Adapun teknik pengambilan data yang digunakan dalam penelitian ini adalah dengan menggunakan kuesioner. Hasil dari kuesioner diukur menggunakan skala likert dengan skala 
sangat tidak puas hingga sangat puas. Pada penelitian ini dalam melakukan teknik analisis data peneliti menggunakan teknik analisis statistika deskriptif, uji validitas, uji reliabilitas, uji normalitas, analisis regresi linier sederhana, dan uji t yang akan diolah dengan menggunakan program komputer aplikasi statistical package for social science (SPSS) for windows.

Dari hasil pengujian instrument penelitian semua item variable penelitian telah valid dan realibel serta data telah berdistribusi normal.

\section{Analisis Data dan Pembahasan}

\section{Hasil Analisis Regresi Linear Sederhana}

Berdasarkan hasil olah data yang digunakan untuk mengetahui pengaruh antar variable dependen dan independen yang dilakukan sebagai berikut.

Tabel 2 Hasil analisis regresi linear sederhana Coefficients

\begin{tabular}{ccccc}
\hline Model & $\begin{array}{c}\text { Unstandardized } \\
\text { Coeffisients }\end{array}$ & $\begin{array}{c}\text { Standardized } \\
\text { Coeffisients }\end{array}$ & $\boldsymbol{t}$ & Sig \\
\hline 1(constant) & B & Std. Eror & Beta & \\
Sisa hasil usaha & .458 & 2,387 & 8,446 & 000 \\
Sumber: Data primer diolah & & .61 & 7,516 & .075 \\
\hline
\end{tabular}

Dari tabel 2 tersebut pada kolom B, tercantum nilai konstanta dan nilai koefisien regresi linear sederhana untuk variabel bebas. Berdasarkan nilai tersebut maka dapat di tentukan nilai regresi linear sederhana yang di nyatakan dalam persamaan sebagai berikut: $\mathbf{Y}=\mathbf{2 0 . 1 6 2 + 0 , 4 5 8 X}$ Dari persamaan tersebut, hasil persamaan regresi linear sederhana dapat berarti bahwa:

a. Konstantanya yaitu sebesar 20,162 jika variabel pembagian sisa hasil usaha di asumsikan tetap, maka penambahan modal usaha anggota akan meningkat sebesar 20,162

b. Nilai koefisien regresi untuk variabel pembagian sisa hasil usaha $(\mathrm{X})$ pada persamaan regresi linear sederhana menunjukan nilai posotif 0,458. Dapat di artikan bahwa jika variabel pembagian sisa hasil usaha meningkat $1 \%$ maka penambahan modal usaha anggota akan meningkat sebesar 0,458\%.

Dari hasil pengujian koefisien regresi linear sederhana tersebut di atas maka di peroleh kesimpulan bahwa pembagian sisa hasil usaha (SHU) berpengaruh positif terhadap penambahan modal anggota koperasi cahaya pertama mandiri.

\section{Uji-t}

Uji ini di gunakan untuk mengetahui apakah model regresi pada tingkat pembagian sisa hasil usaha (SHU) berpengaruh secara signifikan terhadap penambahan modal usaha anggota koperasi. Berikut ini akan di jelaskan pengujian variabel, perhitungan statistik dalam uji-t secara persial dengan menggunakan bantuan program komputer aplikasi statistical package for social science (SPSS) for windows, selanjutnya hasil uji-t dapat dilihat pada tabel sebagai berikut: 


\begin{tabular}{ccccc} 
Model & $\begin{array}{c}\text { Unstandardized } \\
\text { Coeffisients }\end{array}$ & $\begin{array}{c}\text { Standardized } \\
\text { coeffisients }\end{array}$ & $\boldsymbol{t}$ & Sig \\
\hline B(constant) & 20.162 & Std. Eror & Beta & \\
Sisa hasil usaha & .458 & 2,387 & 8,446 & 042 \\
\hline
\end{tabular}

Dependent variabel penambahan modal usaha anggota

Sumber: Data primer diolah

\section{Intrepertasi:}

a. Perumusan hipotesis

Ha: Diduga pembagian SHU berpengaruh secara signifikan terhadap penambahan modal usaha anggota koperasi Cahaya Pertama Mandiri

Ho: Diduga penambahan SHU tidak berpengaruh secara signifikan terhadap penambahan modal usaha anggota koperasi Cahaya Pertama Mandiri

b. Dari tabel di atas di lihat bahwa koefisien variabel pembagian sisa hasil usaha yaitu sebesar 0,458 dan memiliki nilai signifikasi sebesar 0,042. Nilai koefisien 0,458 menunjukan arah pengaruh yang positif variabel pembagian sisa hasil usaha (SHU) terhadap penambahan modal usaha anggota koperasi, sedangkan nilai signifikasi sebesar 0,000 memiliki arti bahwa, taraf signifikasi tersebut lebih kecil dari 0,05.yaitu $(0,000<0,05)$, yang berarti bahwa penelitian ini menerima Ha dan menolak Ho.

\section{Pembahasan}

Dari tabel di atas di lihat bahwa koefisien variabel pembagian sisa hasil usaha yaitu sebesar 0,458 dan memiliki nilai signifikasi sebesar 0,042. Nilai koefisien 0,458 menunjukan arah pengaruh yang positif variabel pembagian sisa hasil usaha (SHU) terhadap penambahan modal usaha anggota koperasi, sedangkan nilai signifikasi sebesar 0,000 memiliki arti bahwa, taraf signifikasi tersebut lebih kecil dari 0,05 yaitu $(0,000<0,05)$, yang berarti bahwa penelitian ini menerima Ha dan menolak Ho. Hasil penelitian penelitian ini mendukung penelitian terdahulu telah dilakukan oleh Hasil penelitian (Astary, 2015) simpanan anggota berpengaruh signifikan terhadap sisa hasil usaha. Penelitian (Setiyono, 2009) modal sendiri, modal asing dan volume usaha berpengaruh signifikan terhadap sisa hasil usaha. Sari dan Susanti (2015) hasil penelitiannya yaitu modal sendiri, modal luar dan volume usaha secara bersama-sama mempengaruhi sisa hasil usaha (SHU). Penelitian (Mailiya, 2005) ada pengaruh yang signifikan antara modal sendiri dan modal pinjaman terhadap SHU. Penelitian (Suteja, 2016) bahwa modal sendiri berpengaruh signifikan terhadap terhadap perolehan SHU dengan $t$ hitung lebih besar dari pada t tabel. Temuan (Malinda, 2015) menemukan sisa hasil usaha koperasi dapat dipengaruhi oleh jumlah anggota dan simpanan anggota. Menurut (Mulyanti \& Rina, 2017) Modal bagi koperasi memiliki peranan penting dalam memperbesar volume usaha yang akan berimbas pada laba yang diperoleh. Selain modal, intensitas pemberian pinjaman pada anggota juga memiliki peran dalam meningkatkan pendapatan Koperasi berupa SHU. Hasil berbeda ditemukan pada (Thamrin, 2013) simpanan anggota secara parsial tidak berpengaruh pada peningkatan SHU. Dalam hasil temuanya (Mulyanti \& Rina, 2017) menunjukkan adanya 
pengaruh yang berbanding terbalik antara modal sendiri dan pemberian pinjaman, serta peningkatan SHU dapat ditingkatkan melalui pemberian pinjaman. Artinya peningkatan modal anggota tidak selalu bersumber dari pembagian SHU.

Menurut (Malinda, 2015) tanpa adanya modal, suatu usaha yang bersifat ekonomis tidak akan dapat berjalan sebagaimana mestinya. Besar kecilnya modal yang ada pada koperasi akan berpengaruh terhadap aktivitas koperasi itu sendiri, dengan demikian faktor modal dalam koperasi ini merupakan salah satu alat yang ikut menentukan maju mundurnya koperasi. Menurut (Malinda, 2015) Keaktifan anggota berpartisipasi dapat berupa aktif dalam transaksi kegiatan usaha dan juga dalam pembiayaan koperasi berupa simpanan pokok, simpanan wajib, simpanan sukarela serta pemanfaatan berbagai potensi usaha pelayanan yang disediakan koperasi akan meningkatkan modal koperasi, terutama modal kerja dam omset usaha koperasi. Hal ini tentu akan membuat koperasi berkembang menjadi lebih baik dan akan menguntungkan anggota terutama dengan adanya kenaikan perolehan sisa hasil usaha koperasi.

\section{Kesimpulan Dan Rekomendasi Kesimpulan}

Dari hasil olah data penelitian yang dilakukan maka dapat disimpulkan sebagai berikut:

SHU berpengaruh positif dan signifikan terhdap penambahan modal anggota dengan sumbangsih sebesar 0,458 dengan artian pembagian SHU terhadap penambahan modal usaha anggota memberikan kontribusi sebesar 45\%, ini menunjukan terdapat $55 \%$ sisanya dipengaruhi oleh indicator diluar dari penelitian ini.

Hasil penelitian inipun memberikan kontribusi pada pembagian SHU terhadap penambahan modal usaha anggota koperasi dengan nilai signifikasi sebesar 0,000 memiliki arti bahwa, taraf signifikasi tersebut lebih kecil dari 0,05 yaitu $(0,000<0,05)$ Yang berarti bahwa penelitian ini menerima Ha dan menolak Ho. Serta subangsih tingkat pembagian sisa hasil usaha koperasi mengalami peningkatan yang baik sehingga penambahan modal usaha anggota koperasi meningkat secara signifikan.

\section{Rekomendasi}

Berdasarkan penelitian dapat diketahui bahwa pembagian sisa hasil usaha (SHU) berpengaruh signnifikan terhadap penambahan modal anggota koperasi, di sarankan pada koperasi agar dapat mempertahankan kualitas dan mengembangkan koperasi agar semakin maju dan lebih baik lagi. 


\section{Daftar Pustaka}

Astary, A. (2015). Pengaruh Jumlah Anggota, Jumlah Simpanan Dan Pinjaman Anggota Terhadap Sisa Hasil Usaha (SHU) Pada Koperasi Karyawan Timah Mitra Mandiri Pangkalpinang.

Mailiya, C. (2005). Pengaruh Modal Sendiri Dan Modal Pinjaman Terhadap Sisa Hasil Usaha ( Shu ) Pada Se Kabupaten Demak. Fakultas Ilmu Sosial Jurusan Ekonomi.

Malinda, yola. (2015). Pengaruh Jumlah Anggota Dansimpanan Anggota Terhadap Peningkatan Sisa Hasil Usaha (Shu) Pada Pkp-Ri (Pusat Koperasi Pegawai Republik Indonesia) Propinsi $\begin{array}{llll}\text { Sumatera } \quad \text { Barat. } & \text { Economica, } & \text { 116-125. }\end{array}$ https://doi.org/10.22202/economica.2014.v2.i2.224

Mulyanti, D., \& Rina. (2017). Meningkatkan Sisa Hasil Usaha Melalui Modal. Ecodemica, 1(1), 81-88.

Retrieved

from http://ejournal.bsi.ac.id/ejurnal/index.php/ecodemica/article/view/1431\%0A

Setiyono, A. (2009). Pengaruh Modal Sendiri, Modal Asing, Dan Volume Usaha Terhadap Sisa Hasil Usaha Pada Koperasi Unit Desa (Kud) Kabupaten Kebumen. 89.

Sugiyono. (2017). Metode Penelitian Kuantitatif, Kualitatif. Bandung: Alfabeta.

Suteja, G. P. (2016). Pengaruh Jumlah Modal Sendiri Dan Jumlah Modal Pinjaman Terhadap Perolehan Sisa hasil Usaha Pada KPN Praja Mukti Kantor Bupati Buleleng Tahun 20062015. Program Studi Pendidikan Ekonomi, 7(2).

Thamrin, M. (2013). Pengaruh Simpanan Dan Pinjaman Anggota Terhadap Sisa Hasi Usaha Koperasi Credit Union Pancuran Hidup Pekanbrabu. Pekbis Jurnal, 5(1), 64-72. 
REKAN

Riset Ekonomi. Akuntansi dan Perpajakan
Vol. 2 No. 1 Maret 2021

e-ISSN : 2721-4109

DOI: 10.30812/rekan.v2i1.1134 